\title{
Flood Pulse and Aquatic Habitat Dynamics of The Sentarum Floodplain Lakes Area
}

\author{
H. Hidayat ${ }^{\text {a,*, Siti Aisyah a }}{ }^{\text {, Riky Kurniawan }}{ }^{\text {a }}$, Iwan Ridwansyah a ${ }^{\text {, Octavianto Samir a }}$, \\ Gadis Sri Haryani ${ }^{\text {a }}$
}

\author{
${ }^{a}$ Research Center for Limnology-LIPI; Kompleks LIPI Cibinong, Jalan Raya Bogor, Km. 46, Cibinong 16911; \\ *hidayat@limnologi.lipi.go.id
}

\begin{abstract}
The Lake Sentarum is a complex of floodplain lakes in the middle part of the Kapuas River system in West Kalimantan, Indonesia. The area has a great ecological and economic importance, however, the Sentarum lakes complex and its catchment area are generally threatened by deforestation, fire, monoculture agroindustry, and pollution.The objective of this research is to establish the hydrological characteristics of the Sentarum lakes area and to reveal the dynamics of aquatic habitat resulted from changing water levels. Data were collected during our field campaigns of 2013-2017 representing the seasons. The water level was measured using a pressure sensor placed at the Lake Sentarum National Park resort, while rainfall data were obtained from the data portal of the Tropical Rainfall Measuring Mission. Inundation monitoring was carried out using a time-lapse camera. A hydrological model is used to simulate water levels beyond measurement period. Water quality and fish sampling were carried out at the lake area. Vegetation observation was carried out at the selected riparian zone of the lake area using the line transect method. Water level records show that the Sentarum floodplain lakes have two peaks of inundation period following the bimodal pattern of rainfall in the equatorial Kapuas catchment. This water level dynamics induced changes in water quality, nutrient availability, vegetation cover, and fish diversity found in the Sentarum lakes area. Despite its seasonal changes, water quality of Sentarum lakes is generally good and suitable for aquatic biota. Fish diversity of the Sentarum lakes is relatively higher during high water periods.
\end{abstract}

Keywords: Flood pulse, floodplain lake, aquatic habitat, data-driven model, Lake Sentarum.

\section{INTRODUCTION}

The Lake Sentarum is a complex of floodplain lakes in the middle part of the Kapuas River system in West Kalimantan, Indonesia. As a wetland area characterized by seasonal inundation, the Sentarum floodplain lakes have flood pulse that is determined by hydrological factors in the area as well as the upstream part of the Kapuas catchment. In wetland with flood pulse, there is a strong correlation between hydrological variation and aquatic biodiversity

* Corresponding Author. Tel: +62-218757071

E-mail: hidayat@limnologi.lipi.go.id

OMLI 2020 with apparent spatial and temporal variability (Davidson et al., 2012). Therefore, a synthesis from hydrological and ecological studies will enhance understanding of how and why water chemistry properties and aquatic biodiversity are varied among different times and locations.

The Sentarum lakes area consists of small and large lakes, peat swamp forest, and freshwater swamp forest forming a vast natural reservoir (Figure 1). Its open water area can reach a maximum area of about $1,000 \mathrm{~km}^{2}$ that can store about 3 billion $\mathrm{m}^{3}$ of water (Hidayat et al., 2017). During the long dry season, most of the lakes are 
dry, while during the rainy season the wetlands of the Sentarum lakes area are inundated forming a large shallow lake as shown in the Landsat images (Figure 2).

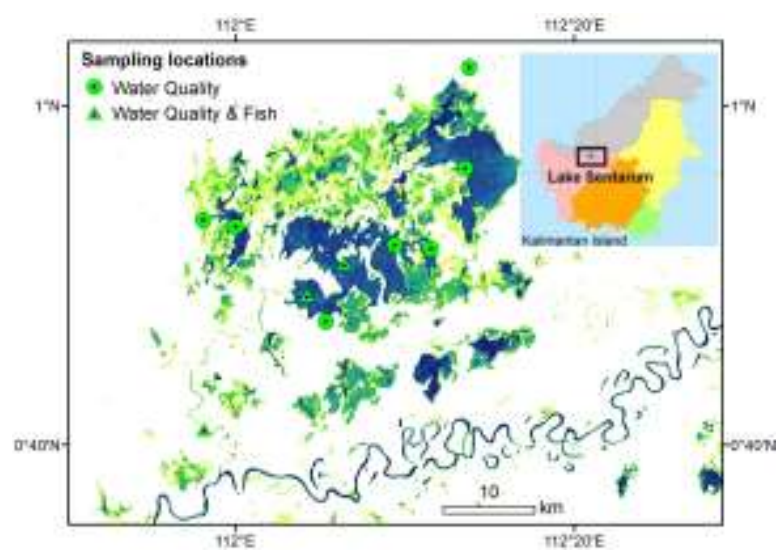

Figure 1. Map of the Sentarum lakes area generated from radar images (Hidayat et al., 2017).

The Sentarum lakes area is important for productive fisheries and has become a major source of livelihood for local people. This floodplain lake area in Kapuas Hulu Regency produces about 18,000 tons of freshwater fish annually (BPS Kalbar, 2015). Most of the fish products are in the form of salted dried fish, which are traditionally processed on-site. Apart from its great ecological and economic importance, the Sentarum lakes complex and its catchment area are generally threatened by deforestation, fire, monoculture agroindustry, and pollution (Rautner et al., 2005).

The flood pulse concept (Junk et al., 1989) explains the cycle of rising and falling water levels in floodplain areas along with aquatic productivity and habitat diversity. The understanding of natural flooding regimes in river-floodplain systems is a key factor in ensuring the long-term integrity of the environmental services they provide. The objective of this research is to establish the flood pulse and to reveal the dynamics of the aquatic habitat of the Sentarum lakes area.
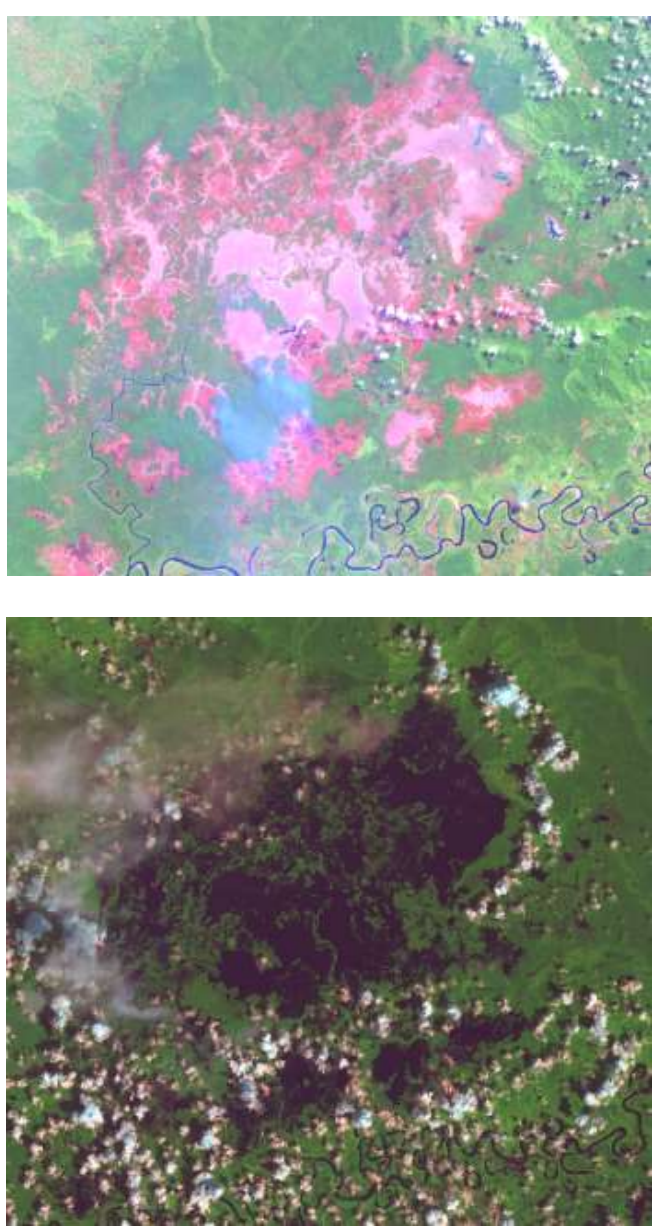

Figure 2. Dry condition on 1 July 2004 (top), fully inundated on 1 October 2015 (bottom) of Lake Sentarum from Landsat images.

\section{METHODS}

Data were collected during our field campaigns in the Sentarum lakes area representing the seasons during the period of 2013-2017. The habitat type of the research area is of typical floodplain area with seasonal fluctuation of water levels driven by rainfall rate. Rainfall data were obtained from the data portal of the Tropical Rainfall Measuring Mission (TRMM). The TRMM data has been available since the launch of the satellite in 1997 with a spatial resolution of $0.25^{\circ} \times 0.25^{\circ}$ and covers areas between latitude $50^{\circ}$ North and South (Huffman et al., 2007). Rainfall climatology characteristics were obtained by averaging the monthly TRMM 3B43 data of 1998 through 2015. Water level was measured using a pressure 
sensor placed at the Lake Sentarum National Park resort.

A data-driven hydrological model was used to simulate water levels beyond measurement period. Simulated discharge obtained from the hydrological model of the Kapuas upstream of Sanggau (Hidayat, 2018a) along with 10-day moving average of the 3B42 daily TRMM rainfall estimates over the lakes complex was used as the input for the data-driven model to simulate water levels of the Sentarum lakes area. Sanggau is located about $350 \mathrm{~km}$ downstream of the Tawang River, the connecting channel between the Sentarum lakes area and the Kapuas river. Figure 3 shows the Kapuas catchment upstream of Sanggau delineated using the Shuttle
Radar Topographic Mission (SRTM) Digital Elevation Model (DEM) (Jarvis et al., 2008).

The water level modeling was carried out using the Waikato Environment for Knowledge Analysis (WEKA) software (Witten \& Frank, 2000). A linear regression function was chosen to model the Sentarum Lake water levels. The time series of water levels, simulated discharge, and the 10-day moving average of TRMM rainfall estimates over the lakes complex was divided into two series: training data series and validation data series. The training data series (Figure 4; top panel) were used for the modeling process with WEKA while the validation data series (Figure 4; bottom panel) were used to verify the model result.

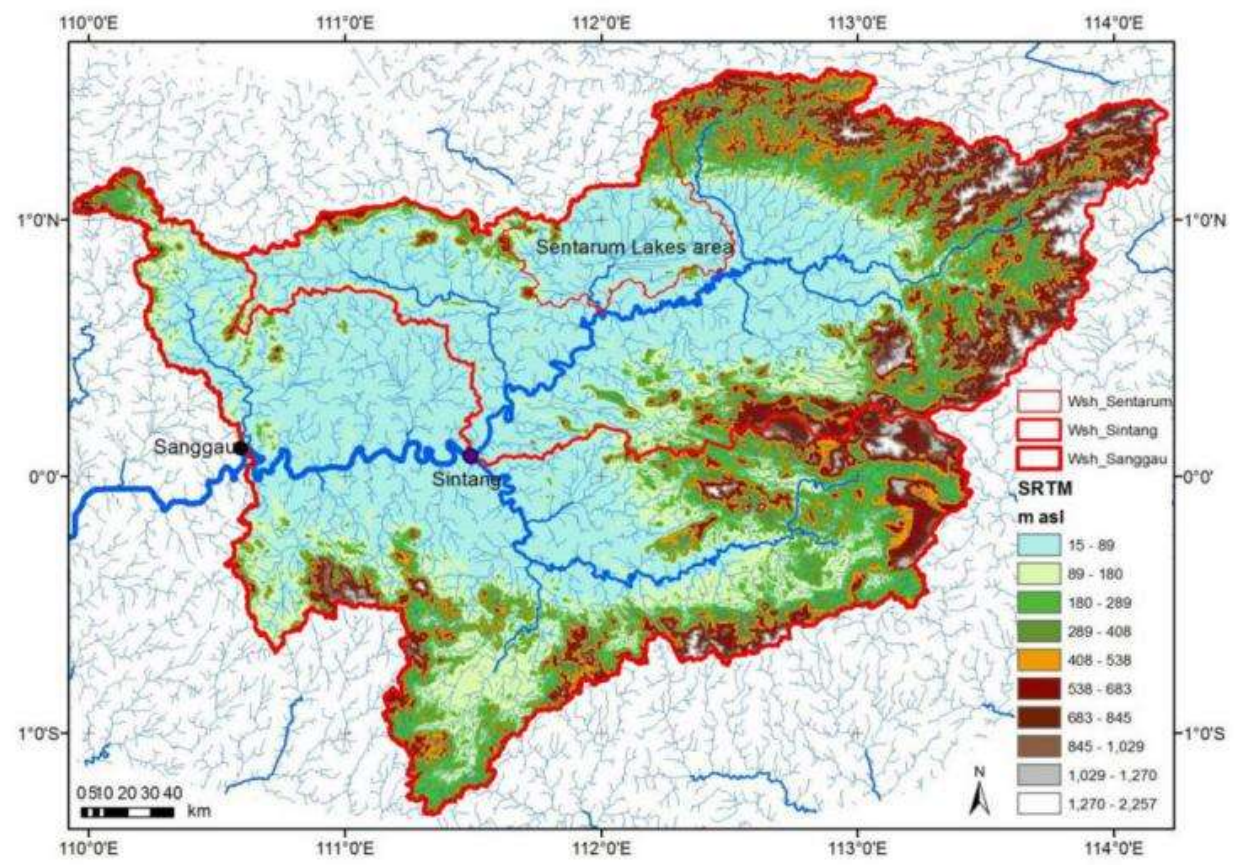

Figure 3. The Kapuas catchment upstream of Sanggau delineated using the SRTM DEM. Blue lines indicate stream network; red lines indicate catchment boundary. 

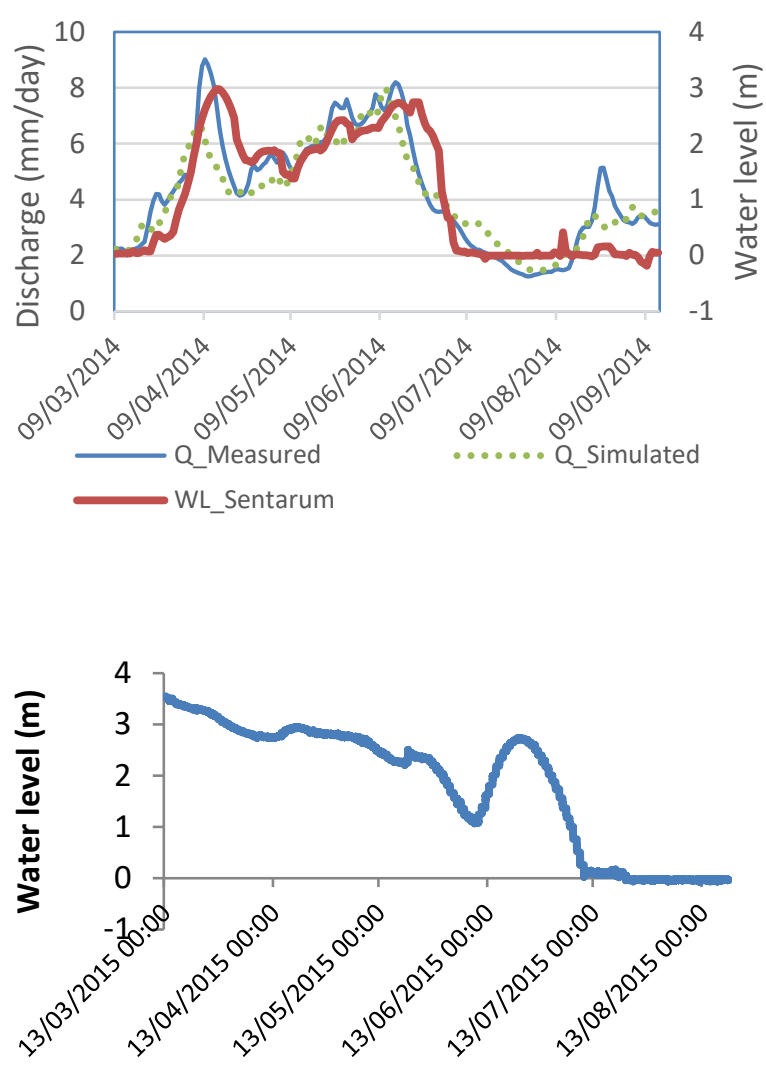

Figure 4. Top: Discharge (Q) of the Kapuas at Sanggau plotted along with water level data of Lake Sentarum. Bottom: Measured water level of Lake Sentarum used as validation dataset of the water level model. Water levels are concerning for the pressure gauges position.

The Nash-Sutcliffe coefficient of Efficiency (NSE) was used to evaluate the model. The NSE measures model ability to predict variable different from the mean, and gives the proportion of the initial variance accounted for by the water level model:

$$
N S E=1-\frac{\sum_{t=1}^{n}\left[W L_{o b s}(t)-W L_{s i m}(t)\right]^{2}}{\sum_{t=1}^{n}\left[W L_{o b s}(t)-W L_{o b s}\right]^{2}}
$$

where:

$W L_{o b s}=$ observed water level at time $\mathrm{t}$;

$W L_{\text {sim }}=$ simulated water level at time $\mathrm{t}$;

$\overline{W L_{o b s}}=$ mean observed water levels;

and $\mathrm{n}=$ total number of time steps.
Vegetation observation was carried out by field observation carried out at the selected riparian zone of the lake area using the line transect method of $50 \times 20 \mathrm{~m}$ with three replicates. Water quality sampling was carried out at 12 locations in the lakes area in 2013, 2016, and 2017 representing the wet, transitional, and dry seasons. Range of water depth at the sampling station was 1.5-9.4 m, depending on the seasons. Water samples were taken using 2-L Kemmerrer Water Sampler at the lake surface and bottom. Analyzed water quality parameters include water temperature, $\mathrm{pH}, \mathrm{DO}$, conductivity, nitrite, nitrate, ammonium, Total $\mathrm{N}$, Total $\mathrm{P}$, and organic matter (TOM). Fish community data were obtained from Haryani et al. (2020), with sampling conducted in March, June, October 2013, and March, June 2014 using experimental gill nets. The fish sampling locations were (see Haryani et al., 2020 for the detail of the experiment).

\section{RESULTS AND DISCUSSION}

\section{Rainfall}

Eighteen-year record of TRMM rainfall estimates reveals that the rainfall pattern over the Kapuas catchments is bimodal with an average annual rainfall of about $3600 \mathrm{~mm}$. The rainfall peak occurs in December-January, with the second peak in March-April and June-August being the driest months. Figure 5 shows the rainfall climatology of the Kapuas watershed that includes the Sentarum lakes area.

Rainfall in Kalimantan is affected by the climate teleconnection associated with the oceanatmosphere circulation phenomenon known as El-Nino and Southern Oscillation (ENSO) (Hidayat, 2018a). Using the TRMM data and two ENSO-related indices, the Southern Oscillation Index and the Multivariate ENSO Index, it is shown that in general the relatively high correlation between rainfall and ENSO index is encountered during the dry season. This climate variability is one of key factors determining rainfall variation that regulates the inundation regime of the study area. 


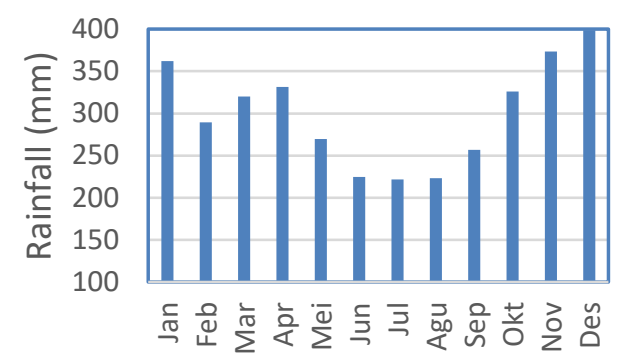

Figure 5. Rainfall climatology of the Kapuas watershed that includes the Sentarum lakes area obtained by averaging the monthly TRMM 3B43 data of 19982015.

\section{Water Level}

Water level records show that the Sentarum floodplain lakes have two peaks of inundation period following the bimodal pattern of rainfall in the equatorial Kapuas catchment. The water level data of the Sentarum Lake are strongly correlated with measured discharge (Hidayat et al., 2017) and simulated discharge (Hidayat, 2008a) of the Kapuas River at Sanggau (Figure 6; top panel). Although the Sentarum lakes area is located far upstream of the Kapuas discharge station at Sanggau, the lake water level data show a high correlation, with a time lag. A maximum correlation of nearly 0.9 was reached on the time lag of lake water level 5 days behind discharge at Sanggau (Figure 6).

From the data-driven modelling of the Sentarum Lake water level (WL), we obtained a linear model:

$$
\mathrm{WL}=0.6454 * \mathrm{Q}_{\operatorname{sim}}+-0.0074 * \mathrm{P}_{10}+-1.025
$$

where $\mathrm{Q}_{\text {sim }}$ is simulated discharge at Sanggau from the previous research (Hidayat, 2008a) and $\mathrm{P}_{10}$ is the 10-day moving average of TRMM rainfall estimates over the lakes complex.

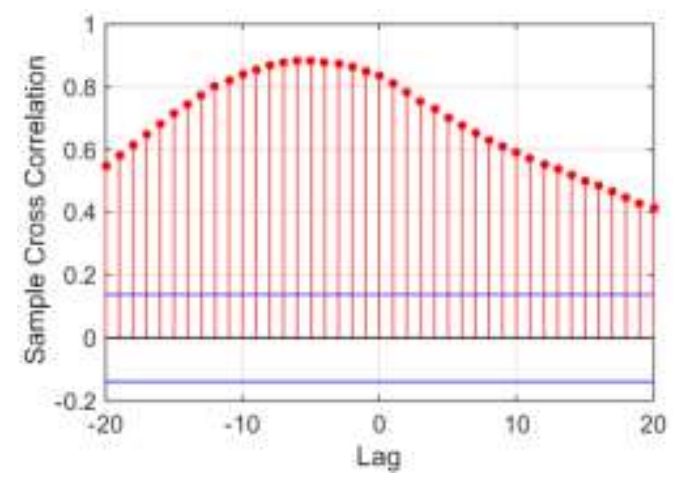

Figure 6. Cross-correlation between lake water levels and discharge of the Kapuas at Sanggau station.

Model evaluation using the Nash-Sutcliffe coefficient of Efficiency (NSE) indicates that the model is relatively well-performed with an NSE of 0.85 . This model, however, still has a relatively large bias during the recession period from high to low water level conditions as well as in modelling low water level conditions. This could be due to the limitation of model input and also the length of the training and validation dataset, which are too short. We also performed water level modelling using M5 Model Tree, a more complex model available in WEKA (not shown), which resulted in a lower NSE value.

Using the linear model (Equation 2), a series of the Sentarum Lake water level estimates were reconstructed as shown in Fig. 7. Negative values on the reconstructed water level series is acceptable as the water levels data used for training and validating the data driven model were not taken on the deepest location, but rather on the shores of the lake. The range of water level of $8 \mathrm{~m}$ simulated by the data-driven model is similar to that of previous physically-based modelling work of the Sentarum floodplain lakes (Bol, 2015). The accuracy of the data-driven water level simulation can be improved by extending the length of training and validation dataset. 


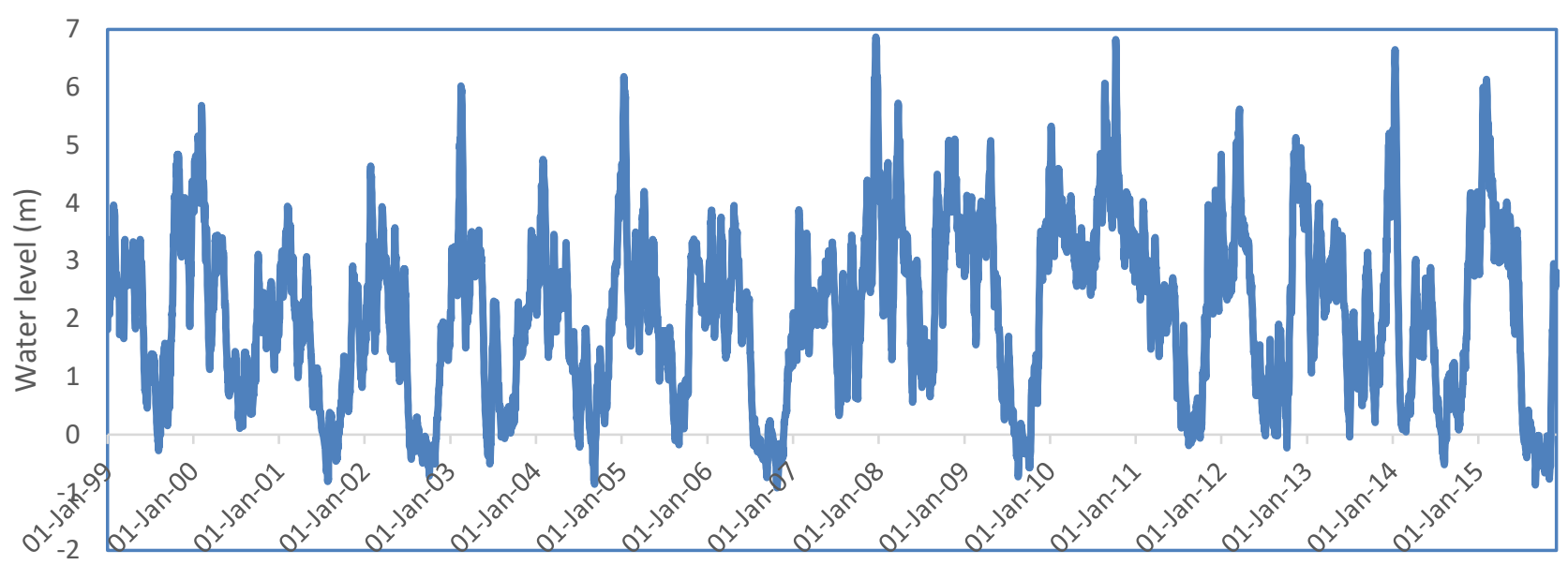

Figure 7. Reconstructed water levels of the Sentarum Lakes (1999-2015) using simulated discharge of the Kapuas main river at Sanggau and TRMM rainfall estimates.

Table 1. Total counts of riparian vegetation found in the Sentarum lakes area

\begin{tabular}{ccccc}
\hline No & Species & Tocal name & $\begin{array}{c}\text { Total count } \\
\text { per species }\end{array}$ & \% \\
& & & & \\
\hline 1 & Barringtonia acutangula (Lecythidaceae) & Putat & 2083 & 20.49 \\
2 & Maranthes corymbosa (Chrysobalanaceae) & Melayak & 2606 & 25.63 \\
3 & Carallia brachiata (Anisophyllaceae) & Kayu tahun & 79 & 0.77 \\
4 & Syzygium sp (Myrtaceae) & Kemasung & 413 & 4.06 \\
5 & Syzygium cf. Medium (Myrtaceae) & Kayu ubah & 6 & 0.06 \\
6 & Syzygium medium (Myrtaceae) & Jijap & 37 & 0.36 \\
7 & Garcinia borneensis (Clusiaceae) & Empanak & 7 & 0.07 \\
8 & Timonius salicifolius (Rubiaceae) & Temirit & 637 & 6.26 \\
9 & Ixora salicifolia (Rubiaceae) & Mentangis & 2137 & 21.02 \\
10 & Pandanus helicopus (Pandanaceae) & Rasau & 220 & 2.16 \\
11 & Malotus sumatranus (Euphorbiaceae) & Belanti & 1 & 0.01 \\
12 & Crateva sp. (Capparaceae) & Punggu & 11 & 0.11 \\
13 & Crudia tenuipes (Fabaceae) & Timba tawang & 1 & 0.01 \\
14 & Memecylon edule (Melastomataceae) & Kebeusi & 1930 & 18.98 \\
\hline & Total individuals & & $\mathbf{1 0 1 6 8}$ & $\mathbf{1 0 0}$ \\
\hline
\end{tabular}

\section{Riparian/Swamp Vegetation}

Fourteen riparian vegetation species that belong to 11 families are found in the Sentarum lakes area, three of them are dominant species namely Barringtonia acutangula (Putat), Ixora salicifolia (Mentangis), and Maranthes corymbosa (Melayak). Other species found are
Timonius salicifolius, Syzygium sp., Syzygium medium, Carallia bracteata, Pandanus helicopus, Syzygium cf. Medium, Garcinia borneensis, Memecylon edule, Crudia tenuipes, Mallotus sumatranus, and Crateva sp. Table 1 shows the total vegetation found in the Sentarum lakes area. 
The swamp forest in the lakes area plays an important role in terms of fisheries resources that supports the livelihood of local fishermen as it provides feeding, refuge, spawning, and nursing grounds for fish (Utomo \& Asyari, 1999). Vegetation that is submerged for a long period becomes a habitat for the growth of periphyton and phytoplankton, which are natural feed for fishes. Roots of large and abundant plants are spawning and nursery ground for fishes that safely lay eggs and shelter ground, where fishes build their nest.

Some of vegetation that grows in the Sentarum lakes area is inundated almost all year long (9-11 months), 4-8 months, 2-3 months, and some are never inundated even during the wet season (Giesen, 1995). The vegetation is dead when it is continuously inundated (or vice versa). The dead vegetation is then decomposed and accumulates nutrients that boost the productivity of phytoplankton, zooplankton, and aquatic avertebrates, which provide feed for secondary consumers. This condition supports the Sentarum area as one of productive floodplain lakes with abundant fish populations.

\section{Water Quality}

Water quality observations show that the aquatic environment of the Sentarum lakes area is relatively good for aquatic biota except that at the Seriang station Oxygen concentration of nearly zero was found at the lake bottom. Fig. 8 shows that the low Oxygen concentration occurred mainly on the bottom layer during low water period.

Based on measurement, the lowest water temperature in the study area was $24^{\circ} \mathrm{C}$ during the rainy season and the highest water temperature was $33^{\circ} \mathrm{C}$ during the dry season. Air temperature ranges from $24^{\circ} \mathrm{C}$ to $36^{\circ} \mathrm{C}$. Some dead fish, especially small ones, were found during our observation in the dry season. This could be due to the depletion of Dissolved Oxygen resulting from the increase in water temperature. Water temperature increase of $1^{\circ} \mathrm{C}$ may increase Oxygen consumption of $10 \%$ (Effendi, 2003). This is because the decomposition process is increased during a warmer temperature. Temperature increase of $10 \%$ will increase the decomposition process and double Oxygen consumption (Davis \& Cornwell, 1991).
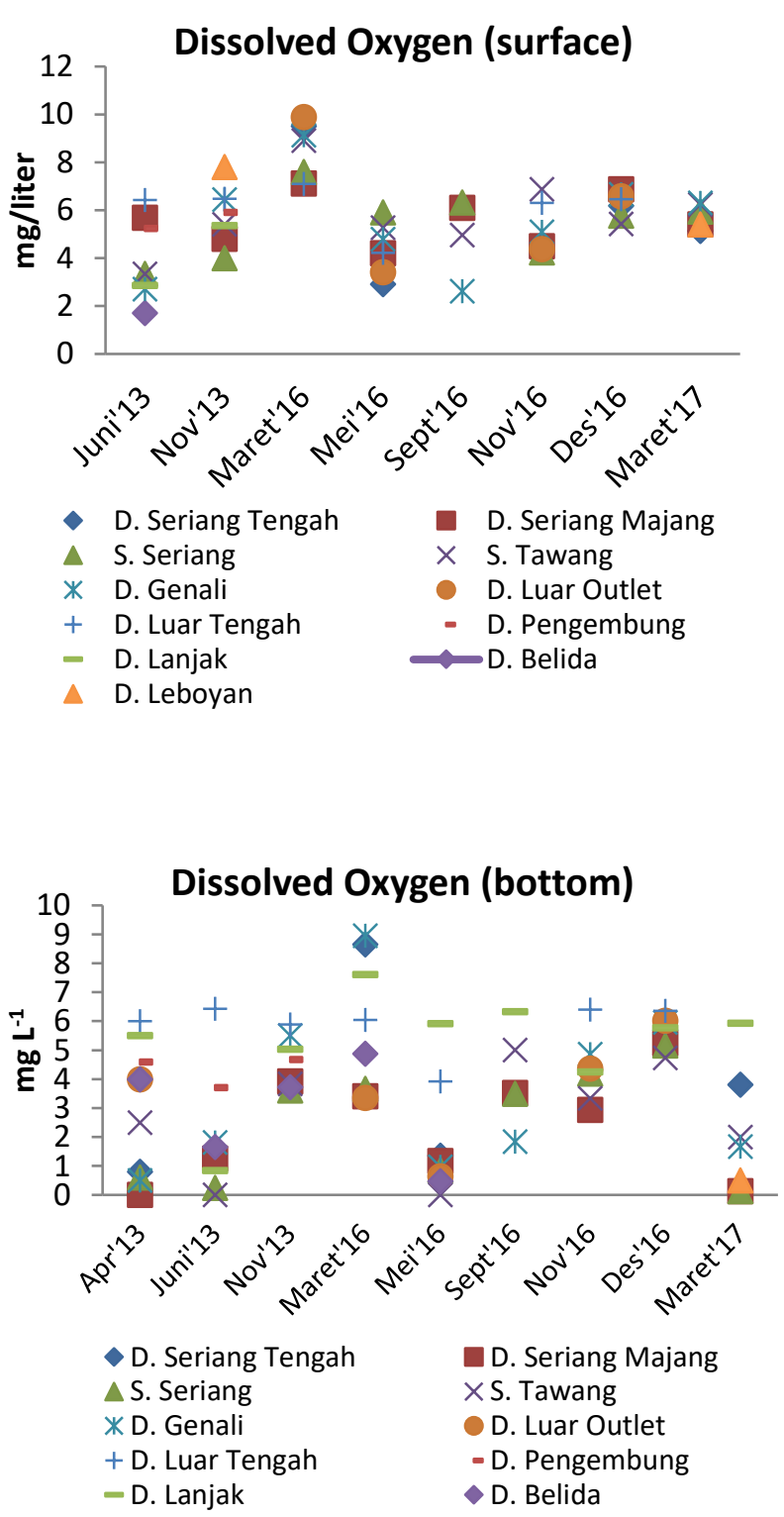

Figure 8. Dissolved Oxygen of the Sentarum lakes area at the surface (top) bottom (bottom) during field observation

Total Nitrogen $(\mathrm{N})$ and Total Phosphorous $(\mathrm{P})$ of Lake Sentarum waters are relatively low with the range of $0.17 \mathrm{mg} \mathrm{L}^{-1}-2.21 \mathrm{mg} \mathrm{L}^{-1}$ and 0.02 $\mathrm{mg} \mathrm{L}^{-1}-0.69 \mathrm{mg} \mathrm{L}^{-1}$, respectively (Figure 9). The sources of these $\mathrm{N}$ and $\mathrm{P}$ nutrients in Lake Sentarum are likely from organic matter of dead animals and plants from allochthonous as well as 
those of autochthonous sources that are decomposed by bacteria. The results of the decomposition process are released into the lake waters. The Sentarum floodplain lakes are inundated during the rainy season as a result of water flow from its catchment area and the overflow from the River Kapuas. During the inundation period, organic matter are released to the lakes, and nutrient concentration tends to increase during low water periods in the dry season.
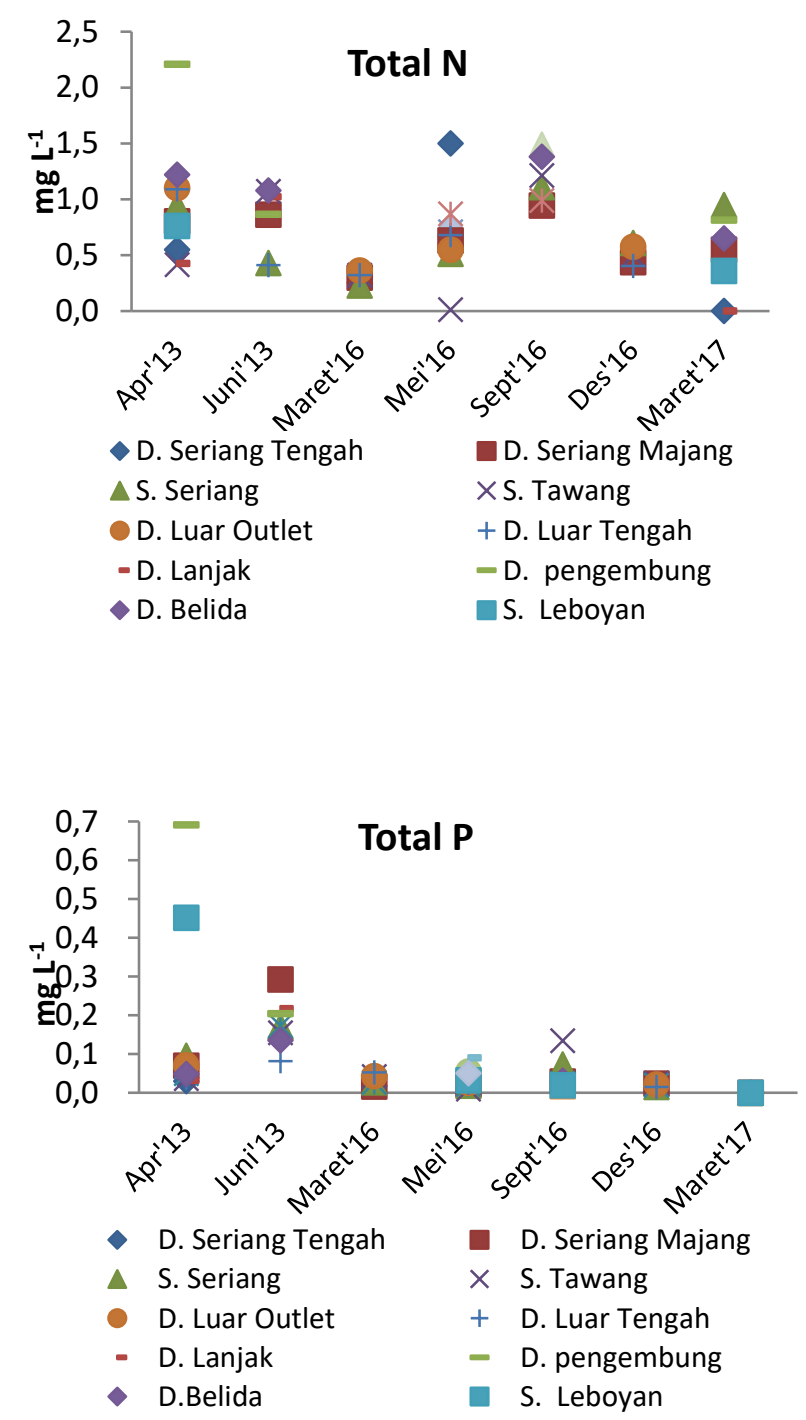

Figure 9. Total Nitrogen (N) and Total Phosphorous (P) of Sentarum Lake waters during observation.

Total organic matter concentration during the study period is ranged between $12.9 \mathrm{mg} \mathrm{L}^{-1}$
$88.6 \mathrm{mg} \mathrm{L}^{-1}$ (Figure 10), which is considered suitable for aquatic biota. Organic matter concentration tends to be low during high water periods. This is likely due to the dilution by rainfall and water overflow from the main river.

\section{Fish Diversity}

Six orders, 15 families, and 39 species of fish were found in Tawang River, Lake Pengembung and Lake Belida in the Sentarum lakes area during the 2013 and 2014 fish sampling (Haryani et al., 2020). Six fish species found belong to black fish category, while five and 28 fish species respectively belong to white and grey fish category. Haryani et al. (2020) found that from the whole sampling period of 2013 through 2014, the total number of species found in the dry season was less ( 20 species) than that in the rainy season (32 species). The observed species diversity can be explained by the water level hydrology - habitat - aquatic productivity migration nexus as exemplified by the 'flood pulse' concept (Haryani et al., 2020).

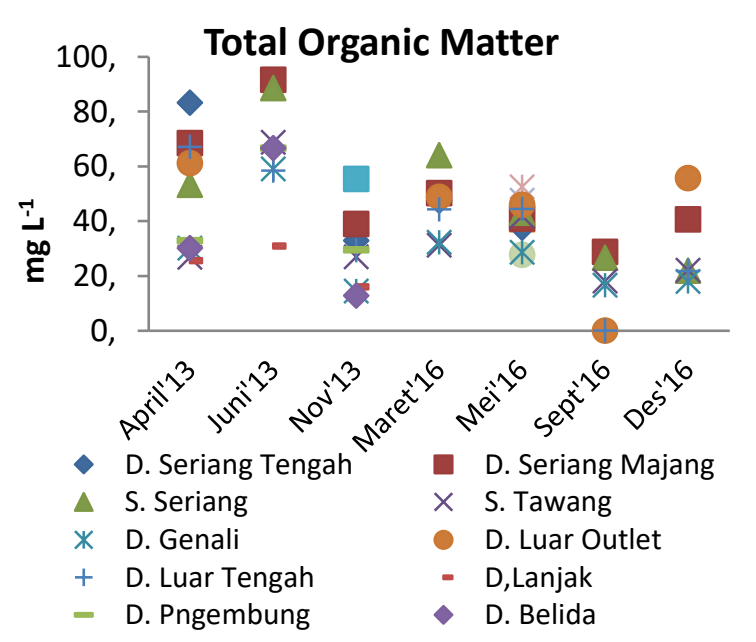

Figure 10. Total Organic Matter during observation.

\section{General Discussion}

Water level in the Sentarum lake area is more determined by its interaction with water level of Kapuas River as a result of fluctuation of rainfall in Kapuas watershed (Hidayat, 2018b). The Tawang River as a link between the Kapuas River and the Sentarum lakes area has a 
bidirectional flow. In the process of lake filling, Tawang River serves as one of the inlets, but during the lakes emptying process it becomes the only outlet for most of the lakes in the Sentarum Lake complex. There is an effective rainfall value of the Kapuas watershed or a certain river water level for initiation of the filling process and discharge of lake area, which needs further investigation.

The lakes area under study is highly dynamic in terms of rainfall depth, inundation area, water levels and this results in the variation of water quality and diversity of aquatic biota. Description of inundation dynamics is important to understand how plants and animals adapt to a habitat that shifts from dry to lentic to lotic, and in quantifying the production of aquatic organisms and ecosystem processes (Schongart \& Junk, 2007).

The flood-pulse triggers ecological processes of floodplain systems inducing a strong seasonality in the annual cycle between the aquatic and the terrestrial phase (Benke et al, 2000). It plays a key role in defining floodplain's plant community composition and distribution, affecting ecosystem processes such as methane emissions, and serving as a habitat for a diverse assemblage of aquatic fauna (Schongart \& Junk, 2007).

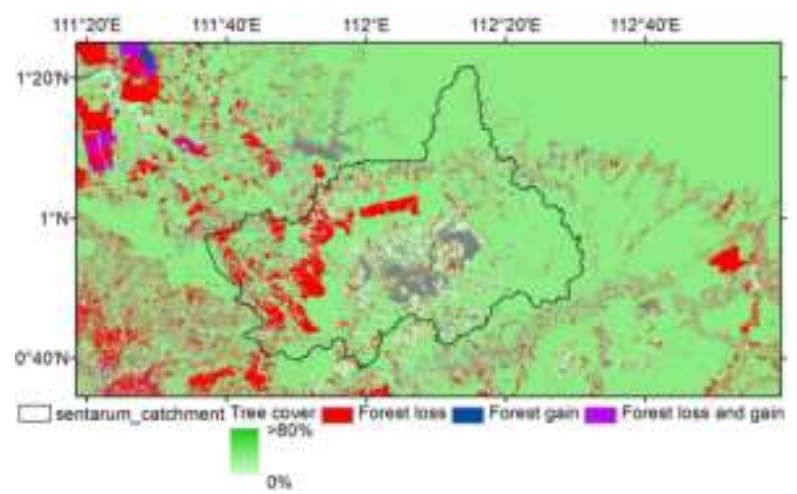

Figure 11. Tree cover (green) forest loss (red) forest gain (blue) with loss and gain (purple) between 2000-2012 in catchment of the Sentarum lakes area. Black line indicates the catchment boundary. Data source: Global Forest Change (Hansen et al., 2013).
Anthropogenic pressure causes land use changes in the catchment area of the Sentarum lakes area such as deforestation and expansion of oil palm. Figure 11 shows forest cover change over the Sentarum lakes area between 2000 and 2012. Oil palm plantations increased by $275 \mathrm{~km} 2$ and farmland increased by $126 \mathrm{~km} 2$ in the catchment area of the Sentarum Lakes for 12 years (2001-2013) (Ridwansyah et al., 2017). Some concerns arise related to water holding capacity, water footprint, water pollution, and sedimentation as the impacts of the expansion of plantations.

Despite its natural state of being wetlands, the Sentarum lakes area is vulnerable to drought, which triggers wildfires that occur almost every year during the dry season. This extreme event may dramatically change the ecological shape of the lowland wetlands. Along with the natural flood pulse impacts, these processes should also be included in the assessment of the wetland status.

\section{CONCLUSION}

Hydrological characterization of the Sentarum Lakes area had been carried out considering the influence of water level changes to aquatic habitat dynamics. Water level dynamics induced changes in vegetation cover, water quality, nutrient availability, and fish diversity found in the Sentarum lakes area.

In general, water quality observations show that the aquatic environment of the Sentarum lakes area is relatively good for aquatic biota. Fish diversity of the Lake Sentarum is relatively higher during high water periods, which can be explained by the water level - hydrology habitat - aquatic productivity - migration nexus.

\section{ACKNOWLEDGEMENTS}

This research was funded by DIPA-SBK project of Research Center for Limnology-LIPI fiscal year 2017, we are grateful to Mr. Tjandra Chrismadha, M.Sc. as the coordinator of the team. 
Contributorship: H.H. is the main contributor of this paper. All other authors contributed equally to this publication.

\section{REFERENCES}

Benke AC, Chaubey I, Ward GM, Dunn EL. 2000. Flood pulse dynamics of an unregulated river floodplain in the southeastern U.S. coastal plain, Ecology, 81(10), 2730-2741. DOI: 10.1890/0012-9658(2000)081[2730:FPDOAU] 2.0.CO;2

Bol D. 2015. The influence of the Upper Kapuas wetland area on the Kapuas flow characteristics, West-Kalimantan, Indonesia: A hydrological modelling study. Master's thesis. Wageningen University.

BPS-Kalbar. 2015. Kalimantan Barat in Figures, BPS-Statistics of Kalimantan Barat. http://kalbar.bps.go.id/website/pdf_publikasi/Kal imantan-Barat-Dalam-Angka-2015.pdf.

Davidson TA, Mackay AW, Wolski P, Mazebedi R, Murray-Hudson M, and Todd M. 2012. Seasonal and spatial hydrological variability drives aquatic biodiversity in a flood-pulsed, sub-tropical wetland. Freshwater Biology, 57, 1253-1265. DOI: $10.1111 / \mathrm{j} .1365-2427.2012 .02795 . x$

Davis ML \& Cornwell DA. 1991. Introduction to Environmental Engineering, $2^{\text {nd }}$ edition. McGraw-Hill, Inc. New York.

Effendi H. 2003. Telaah Kualitas Bagi Pengolahan Sumber Daya dan Lingkungan Perairan. Kanisius, Yogyakarta. (in Bahasa Indonesia).

Giesen W. 1995. The Flood Forest and Black Water Lake of Sentarum Wildlife Reserve, West Kalimantan. AWB-PHPA, Bogor, p 73.

Hansen MC, Potapov PV, Moore R, Hancher M, Turubanova SA, Tyukavina A, Thau D, Stehman SV, Goetz SJ, Loveland TR, Kommareddy A, Egorov A, Chini L, Justice CO, and Townshend JRG. 2013. High-resolution global maps of $21^{\text {st }}$ century forest cover change. Science, 342, 850 853. DOI: $10.1126 /$ science. 1244693

Haryani GS, Hidayat, and Samir O. 2020. Diversity of fish caught using gill nets in Lake Sentarum, West Kalimantan - Indonesia. IOP Conf. Ser.:
Earth Environ. Sci., 535, 012037. DOI: 10.1088/1755-1315/535/1/012037

Hidayat H, Teuling AJ, Vermeulen B, Taufik M, Kastner K, Geertsema TJ, Bol DCC, Hoekman D H, Haryani GS, Van Lanen HAJ, Delinom RM, Dijksma R, Anshari GZ, Ningsih NS, Uijlenhoet R, and Hoitink AJF. 2017. Hydrology of inland tropical lowlands: the Kapuas and Mahakam wetlands. Hydrol. Earth Syst. Sci., 21, 2579-2594. DOI: $10.5194 /$ hess-21-2579-2017

Hidayat. 2018a. Analisis variabilitas iklim pada daerah aliran Sungai Kapuas bagian hulu dan tengah dengan data satelit trmm dan model konseptual. Prosiding Pertemuan Ilmiah Masyarakat Limnologi Indonesia Tahun 2017 (in Bahasa Indonesia).

Hidayat. 2018b. Karakterisasi lahan basah di daerah aliran Sungai Kapuas bagian hulu dengan topographic wetness index dan survey lapangan. Prosiding Pertemuan Ilmiah Masyarakat Limnologi Indonesia Tahun 2017 (in Bahasa Indonesia).

Huffman GJ, Adler RF, Bolvin DT, Gu G, Nelkin EJ, Bowman KP, Yong Y, Stocker EF, and Wolff DB. 2007. The TRMM multi-satellite precipitation analysis (TMPA): Quasi-global, multi-year, combined-sensor precipitation at fine scales. J. Hydrometeor., 8(1), 38-55. DOI: 10.1175/JHM560.1

Jarvis A, Reuter HI, Nelson A, and Guevara E. 2008. Hole-filled seamless SRTM data v4, International Centre for Tropical Agriculture (CIAT), CGIAR website.

Junk WJ, Bayley PB, and Sparks RE. 1989. The flood pulse concept in river-floodplains systems. In: Dodge DP (ed.), Proceedings of the International Large River Symposium. Canadian Special Publication of Fisheries and Aquatic Science, 106, 110-127. available at: ftp://ftp.cs.ru.nl/pub/toinesmits/PDF_files_suppo rting literature 24\%2625-112009/1989JunkThe\%20flood\%20pulse\%20conce pt\%20in.pdf

Rautner M, Hardiono M, and Alfred R J. 2005. Borneo: Treasure Island at Risk, WWF Germany, Frankfurt am Main, assets.panda.org/downloads/ treasureislandatrisk.pdf. 
Ridwansyah I, Nasahara K, Nishiyama C, and Subehi L. 2017. Land use change analysis at Sentarum catchment area, West Kalimantan-Indonesia. Proc. $16^{\text {th }}$ World Lake Conference, Bali.

Schongart J \& Junk WJ. 2007. Forecasting the floodpulse in Central Amazonia by ENSO-indices, Journal of Hydrology, 335. DOI: 10.1016/j.jhydrol.2006.11.005.
Utomo AD \& Asyari. 1999. Peranan ekosistem hutan rawa air tawar bagi kelestarian sumber daya perikanan di Sungai Kapuas, Kalimantan Barat, Jurnal Penelitian Perikanan Indonesia, V(3). (in Bahasa Indonesia).

Witten IH \& Frank E. Data Mining. 2000. Practical Machine Learning Tools and Techniques with Java Implementations. Morgan Kaufmann Publishers, San Francisco, USA. 